\title{
Comparative Costs, Factor Proportions and Industrial Efficiency in Pakistan
}

by

\author{
NURUL ISLAM*
}

The paper presents, in Section I, new and additional evidence on the comparative costs of manufacturing industries in Pakistan. Furthermore, the findings of the present study are compared with those of earlier studies. Comparative costs in this context are defined as the ratios of ex-factory prices of specific domestic products to cif prices of closely competing imports. In Section II, it examines whether the tariff rates are an adequate index of the comparative cost ratios i.e., in other words, whether the differences in the tariff rates reflect the differential cost structure of Pakistani industries? We also examine, in Section III, whether the available data provide any evidence on the relationship between the magnitude of cost disabilities of the Pakistani industries and their stage of infancy, i.e., whether and to what extent cost ratios decline with the growing up of infant industries. This paper also analyses in Sections IV and $V$ how far comparative cost ratios can be used as a measure of the relative inefficiency of industries in Pakistan? How far, for example, the high cost ratios of domestic industries merely indicate that the Pakistani rupee is overvalued? How far the cost ratios are affected by or represent high profits of industries? An attempt is made to adjust for both the overvaluation of foreign exchange and the prevalence of abnormally high profits. Finally, in Section VI, we relate the comparative cost ratios of the manufacturing industries to their factor intensities or their factor proportions in an attempt to explore whether relative efficiency is correlated with the relative intensity of use of the different factors such as capital, labour, and skill.

\section{EVIDENCE ON COMPARATIVE COST RATIOS}

Pakistan's impressive achievement in the growth of the industrial sector has attracted a considerable amount of analysis, especially with respect to the pattern or strategy of industrialisation and the efficiency of the industrialisation programme. This paper is an attempt to analyse the comparative cost structure of the Pakistani industries, based on a direct estimate of the costs of the individual

* Professor Nurul Islam is Director, Pakistan Institute of Development Economics. He is grateful to Professor Marvin E. Rozen and Gordon Winston, Senior Research Advisor and Research Adviser respectively at the Institute for helpful comments on an earlier version of this paper. 
manufactured goods and the cif prices of the closely competing import products. The data are derived from the published and unpublished reports of the Pakistan Tariff Commission on 115 industries scattered over a 15-year period i.e., 1951-661. The analysis covers about 359 products. They in no sense, therefore, constitute a random sample from the manufacturing sector as a whole so as to represent various industrial groups. The most important industries such as cotton textiles, jute textiles, woollen textiles and fertilisers are not included at all in this analysis since they have not been subject to investigation by the Tariff Commission. For the same reason there are also important omissions from within such industry groups as machinery, both electrical and otherwise, and transport equipment. The industries covered here, moreover, range over both the large scale and small scale manufacturing sectors. The difference in cost conditions between large and small firms is ignored in the analysis.

The total number of establishments or firms covered in the present analysis excluding such industries as coir goods industry, washing soap industry, leather footwear industry and bidi industry where small firms predominate, is around 1164. This number, however, still includes a few small firms in a number of industries such as paints and varnishes, non-metallic mineral products, engines turbines etc., which are included in the analysis. Since the number of establishments in the large scale manufacturing sector as reported in the revised 1959-60 Census of Manufacturing Industries is about 3800 , our coverage is quite large 2 .

Does an analysis of the cost ratios of only those industries which have been investigated by the Tariff Commission yield biased results because only inefficient industries will need such intervention? This is unlikely since the great majority of the manufacturing industries in Pakistan have ex-factory prices higher than the competing world prices, and thereby are prospective candidates for protective tariffs. The reasons why some industries come before the Tariff Commission and others do not are not systematically related to their respective relative efficiency. Thus, for instance, some industries receive protection from foreign competition through high revenue tariffs or quantitative restrictions on imports, none of

1 All the data relating to cost ratios, unless otherwise specified, are from [9a]. The specific reports have not been cited and in some cases the reports have not been published so far. The cost data relating to sugar, cement and paper are taken from [3, pp. 121-128].

2 Since data on the value of output of industries covered in this analysis are not available it has not been possible to estimate the proportion of the total industrial output which the industries covered by the present study contribute. However, an attempt is made to compare the number of establishments in specific industry groups which are covered in the present analysis with the number of establishments in corresponding major industry groups which are recorded in the Census of Manufacturing Industries $1959 / 60$ in Appendix B. This comparison only includes those industry groups from the Census, which include commodities investigated by the Tariff Commission 
which require the intervention or investigation by the Tariff Commission. There is likewise no reason to believe that the protective incidence of these measures is systematically related to the comparative cost structure of the industries, since the height of revenue duties or the level of quantitative restrictions is determined primarily without reference to the cost structure of the affected industries. Fiscal and balance of payments considerations are the principal determinants of the levels of these alternative instruments of import restrictions. Therefore, there does not seem to be any strong reason for bias in the sample, one way or the other, with the result that what is true of the given sample of industries in the present study is likely to be broadly true of the whole range of industries in Pakistan.

It is also important to remember that the cost ratios for each industry are the averages of the ratios for the individual products which are included in each industry. There are in some cases important differences in the cost ratios between different products produced by the same industry. While the average cost ratio for the industry as a whole in some cases may be high, individual products may have cost ratios which are highly competitive with imports. Moreover, there are instances where differences in efficiency exist between different firms producing the same product. Again, there are differences in the cif prices of the same product, depending upon the sources of supply. The cost ratios reported in this paper are, however, averages for a number of firms or represent the cost ratio of the representative firm chosen by the Tariff Commission for its cost analysis. The data relate to the years 1951-66 and the different industries are covered in the different years, limiting the value of an intertemporal comparison. Where cost ratios differ because of differences in the cif prices from different sources, an average of the cost ratios based on different cif prices is taken 3 .

The average cost ratios have been computed in three different ways for each of the time periods. Firstly, the simple averages of the cost ratios have been computed for the periods i.e., 1951-55, 1956-60 and 1961-66 respectively. Secondly, for each period, the individual industry ratios have been computed as a simple average of the cost ratios for individual products covered by an industry. The output data relating to individual products are not available;

3[4]. There are in many instances indirect taxes in the form of sales and excise duties on the manufactured goods produced at home. The indirect taxes are not relevant for an analysis of comparative costs and efficiency of the manufacturing industries; however, they affect the prices facing the domestic consumers and the relative use or consumption of the different products is affected by their relative prices, including taxes. The cif prices of competing imports on which comparative cost ratios are based include the costs of transportation, a change which will affect the cif prices and cost ratios. This need to be borne in mind while using cost ratios as an indicator of the cost disability or the relative inefficiency of the Pakistani industries. 
in fact in the majority of the cases, data relating to the value of output of an individual industry are also not available so that they can be used as weights. Accordingly, the number of products produced by each individual industry is used as weights to arrive at estimate of the average cost ratio for all the industries in each of the time periods. Thirdly, an attempt was made to classify the individual industries into major groups, following the classification used by Pakistan Standard Industrial Classification which is also used by the Pakistan Censuses of Manufactures. The cost ratios for these major groups have been computed by weighting the individual industry ratios by the number of products covered by them. But then in the next stage, the cost ratios of the major groups of industries are combined together by using as weights the values of gross output of each of the major groups of industries as given in the censuses. This average cost ratio is obtained for each period. The three sets of ratios are given below:

\section{TABLE I}

COMPARATIVE COST RATIOS4

1951-55

1.43

\begin{tabular}{llllcrl} 
& \multicolumn{7}{c}{ Average Values } \\
(A) & $\ldots$ & 1.56 & $(1.49)$ & 1.40 & 1.83 & $(1.66)$ \\
(B) & $\ldots$ & 1.65 & $(1.57)$ & 1.62 & 1.83 & $(1.70)$ \\
(C) & $\ldots$ & 1.56 & & 1.33 & 2.16
\end{tabular}

$1956-60$

1961-66

Average Values

Median Values

$1.40-1.42 \quad 1.64-1.65$

The cost ratios are based on ex-factory prices without indirect taxes. The (A) ratios are unweighted, simple averages of individual industry ratios; (B) ratios are based on the number of products produced by each industry as weights; and the $(C)$ ratios are based on the number of products as weights for deriving the cost ratios of each major industry group which are then wighted by the values of output of each major group of industry. Each of the three different systems of weighting has its own limitations. The best weights would have been the value of output of each individual industry to which a cost ratio relates. However, data on the value of output of each individual industry are not available. The first method, in fact, implies an equal weight to every ratio. To the extent that the relative numbers of products produced by different industries diverge widely from the relative outputs of different industries, the (B) ratios may contain a

4 The weights for the 1951-55 are obtained from the Censuses of Manufacturing Industry, 1955 [9] and those for 1956/60 from Census of Manufacturing Industries 1959/60 [9]. The weights for 1961-66 are obtained from the unpublished Interindustry Table [5]. 
bias in favour of industries with a greater diversity of products. The (C) ratios are based on the appropriate weights in so far as the weights for the cost ratio of each major group of industry are concerned, even though the cost ratio for each major group suffers from the same limitation as that of the (B) ratios. The (A) and (B) sets of cost ratios are roughly comparable. The changes in the cost ratios of all the three sets between the different time periods are in the same direction. They all go down in the second period and go up in the third. The ratios within brackets exclude the extreme values above 3.00 and they are about 4 to 5 items for the whole period. The ex-factory prices,on the average, are about 50-90 per cent higher than the corresponding cif prices in the different time periods whereas the median values of the excess of the ex-factory price over the cif prices range between $40-65$ per cent.

It may be pointed out, however, that the cost ratios of 3 out of 62 industries in the period 1961-66, 2 out of 29 industries in the period 1951-55, and 5 out of 24 industries in the period 1956-60 were less than one; this implies that they were highly competitive and their prices were less than the cif prices of competing products.

An attempt has been made to classify the industries into three groups, i.e., consumer goods, intermediate goods and raw materials and capital goods and to examine how the cost ratios differ between these three groups of industries which are given below 5 :

\section{TABLE II}

\section{COST RATIOS (WITHOUT INDIRECT TAXES)}

Consumer goods Intermediate goods

Capital goods

$\begin{array}{lllllll}\text { Simple average } & \ldots & 1.58 & (1.34) & 1.78 & (1.68) & 1.70 \\ \text { Median value } & \ldots & 1.40 & 1.58 & 1.62 \\ \text { Weighted average }{ }^{1} & \ldots & 1.60 & (1.43) & 1.87 & (1.77) & 1.77\end{array}$

1 The weighted average ratios used hereafter in this paper are based on number of products relating to a particular industry as weights.

The cost ratios computed by the different methods for consumer goods are consistently lower than those for the other two categories whereas as between the intermediate and capital goods, both the weighted and simple average cost ratios of the former are higher than that of the latter. But the differences between

5 The ratio within brackets exclude extreme values and are weighted averages, weights being the number of products in each industry. 
the cost ratios of the two latter categories virtually disappear when the extreme values are omitted, as indicated in the above table. A more detailed picture of the comparative cost ratios of the three categories of commodities is seen below:

TABLE III

\section{COST RATIOS FOR THREE MAIN CATEGORIES OF INDUSTRIES}

\begin{tabular}{|c|c|c|c|c|c|c|}
\hline \multirow{2}{*}{$\begin{array}{c}\text { Groups } \\
\text { (cost ratios) }\end{array}$} & \multicolumn{2}{|c|}{ Consumer goods } & \multicolumn{2}{|c|}{ Intermediate goods } & \multicolumn{2}{|c|}{ Capital goods } \\
\hline & $\begin{array}{l}\text { Frequency } \\
\text { distribution }\end{array}$ & $\begin{array}{l}\% \text { of total } \\
\text { frequencies }\end{array}$ & $\begin{array}{c}\text { Frequency } \\
\text { distribution }\end{array}$ & $\begin{array}{l}\% \text { of total } \\
\text { frequencies }\end{array}$ & $\begin{array}{l}\text { Frequency } \\
\text { distribution }\end{array}$ & $\begin{array}{l}\% \text { of total } \\
\text { frequencies }\end{array}$ \\
\hline $\begin{array}{l}0.50-0.99 \\
1.00-1.50 \\
1.51-2.00 \\
2.01-2.50 \\
2.51-3.00 \\
3.01-3.50 \\
3.51-4.00 \\
4.01-4.50 \\
4.51-5.00 \\
5.01-5.50 \\
5.51-6.00 \\
6.01-6.50\end{array}$ & $\begin{array}{r}7 \\
21 \\
10 \\
1 \\
1 \\
2 \\
- \\
- \\
1 \\
-\end{array}$ & $\begin{array}{r}16.3 \\
48.8 \\
23.3 \\
2.3 \\
2.3 \\
\overline{4.7} \\
\overline{-} \\
\overline{-} \\
2.3 \\
-\end{array}$ & $\begin{array}{r}1 \\
13 \\
15 \\
8 \\
- \\
1 \\
1 \\
- \\
- \\
-\end{array}$ & $\begin{array}{l}2.6 \\
33.3 \\
38.5 \\
20.4 \\
- \\
\overline{2} \\
2.6 \\
= \\
- \\
-\end{array}$ & $\begin{array}{r}2 \\
12 \\
11 \\
5 \\
3 \\
= \\
= \\
= \\
= \\
=\end{array}$ & $\begin{array}{r}6.0 \\
36.4 \\
33.3 \\
15.2 \\
9.1 \\
= \\
= \\
= \\
= \\
-\end{array}$ \\
\hline & 43 & 100.0 & 39 & 100.0 & 33 & 100.0 \\
\hline
\end{tabular}

The greatest number of consumer goods industries, i.e., 49 per cent of the total, have cost ratios between 1.00 and 1.50 and about 23 per cent have cost ratios between 1.50 and 2.00; in the case of intermediate and investment goods almost equal percentage of industries, i.e., between 33 per cent and 38 per cent, have cost ratios ranging $a$ ) between 1.00 and 1.50 and $b$ ) $1.51-2.00$ respectively. About 20 per cent and 15 per cent respectively of the intermediate and capital goods industries have cost ratios between 2.00 and 2.50 whereas only about 8 per cent of the consumer goods falls in this range. The range of cost ratios derived above seem to compare well with the results of an earlier study ${ }^{6}$. The latter estimates the domestic prices of imports which may be used to derive the $\cos i$ ratios of domestic industries, as shown in the appendix. Inspite of the differences in methods and sources of data as well as in the commodity composition of the two samples, the overall comparability of the two sets of cost ratios adds to the degree of confidence in the general level of cost disability of the different manufacturing industries in Pakistan, as evidenced from the present study.

6 [6]. Unweighted averages in Table IV are simple averages of cost ratios and weights used in the estimation of weighted averages are the values of imports of individual items or of the category of commodity to which the item belongs. 


\section{COMPARATIVE COSTS AND TARIFFS}

A pertinent question relating to the measurement of comparative costs is whether and to what extent tariff rates measure or fail to measure comparative costs. In a regime of quantitative restrictions the usual assumption is that tariffs underestimate the excess cost of the domestic product over the cif price of the competing imports. Theretore, the tariff rates on different commodities may not reflect the cost disadvantages of the producing industries.

Another hypothesis suggests that the excess of ex-factory prices (inclusive of indirect taxes) over landed costs (inclusive of excise and sales taxes) is a uniform percentage of landed costs for all commodities. Thus Soligo and Stern, in their analysis of effective protection, derive the world prices of the domestic products by deflating the domestic prices by tariffs alone, ignoring scarcity margins?. They assume that as a group the scarcity margin is the same for goods and investment goods and that domestic prices are at least equal to cif price of a competing import converted at the official exchange rate plus import duties. Thus where scarcity margins are positive, tariffs alone will understate cost disadvantage, and where scarcity margins are negative, the cost disadvantage of domestic industries will be overstated. The following analysis provides additional evidence on the overall magnitude, both positive and negative, of interindustry differences in scarcity margins.

TABLE IV

RATIO OF ACTUAL EX-FACTORY PRICE INTO LANDED COSTS

\begin{tabular}{ll|c|c|c|cc}
\hline Year & \begin{tabular}{c} 
Equal to one \\
\cline { 1 - 4 }
\end{tabular} & $\begin{array}{c}\text { No. of } \\
\text { items }\end{array}$ & $\begin{array}{c}\text { No. of } \\
\text { items }\end{array}$ & $\begin{array}{c}\text { Average } \\
\text { ratio }\end{array}$ & $\begin{array}{c}\text { No. of } \\
\text { items }\end{array}$ & $\begin{array}{c}\text { Average } \\
\text { ratio }\end{array}$ \\
\hline $1951-55$ & $\ldots$ & - & 9 & 0.75 & 22 & 1.29 \\
$1956-60$ & $\ldots$ & 2 & 21 & 0.72 & 27 & 1.42 \\
$1961-66$ & $\ldots$ & 5 & 47 & 0.75 & 120 & 1.47 \\
\hline
\end{tabular}

In the majority of the cases ex-factory price exceeds landed cost (67 per cent of the total number of items) whereas in 30 per cent of the cases it falls short of the landed cost. In a very few (about 3 per cent) they are equal. The ex-factory price below the landed costs may imply either that for these products the tariffs

7 [1, pp. 249-66]. The landed costs in Tables IV to VII include both the tariffs as well as excise and sales taxes on imports and the ex-factory prices likewise include indirect taxes. The ratios are weighted ratios, weights being the number of products to which each price ratio relates. Each industry ratio is a simple average of the ratios for the different products and the ratios for different industries are weighted by number of products of each industry in order to obtain an overall ratio. 
are redundant, or that the domestic product fetches a lower price because of inferior quality. Even when rates are determined by the Tariff Commission, at a particular moment of time tariffs and quotas may be out of line with the divergence between the cif and the ex-factory price and they need revision which takes place with a time lag. Often these rates and quotas are fixed without reference to the Tariff Commission and hence without any reference to the divergence between the ex-factory price and the cif price of the competing product. Moreover, an industry which starts out with its ex-factory price being equal to or higher than the landed cost, both because of high profits as well as of high costs, may after a period not only reduce costs but also earn lower profits owing to increasing competition.

In many cases the available data on the ex-factory prices relate to fair exfactory prices rather than to actual prices. For the purposes of the estimate of scarcity margins, 'fair' prices have been used only when actual prices are not available so that the former provides an additional evidence on the magnitude of scarcity margins. To the extent that fair prices are lower than actual prices, which is the case in the great majority of the cases, excepting where firms were making losses, the corresponding scarcity margins are an underestimate of the actual scarcity margins. Sixty per cent of the items have positive scarcity margins varying between $43-73$ per cent as seen below:

TABLE V

RATE OF FAIR EX-FACTORY PRICE TO LANDED COSTS

\begin{tabular}{|c|c|c|c|c|c|c|}
\hline \multirow[b]{2}{*}{ Year } & \multirow[b]{2}{*}{. } & \multirow{2}{*}{$\frac{\text { Equal to one }}{\begin{array}{c}\text { No. of } \\
\text { items }\end{array}}$} & \multicolumn{2}{|c|}{ Below one } & \multicolumn{2}{|c|}{ Above one } \\
\hline & & & $\begin{array}{l}\text { No. of } \\
\text { items }\end{array}$ & $\begin{array}{l}\text { Average } \\
\text { ratio }\end{array}$ & $\begin{array}{l}\text { No. of } \\
\text { items }\end{array}$ & $\begin{array}{l}\text { Average } \\
\text { ratio }\end{array}$ \\
\hline $1951-55$ & $\ldots$ & 1 & 23 & 0.80 & 40 & 1.43 \\
\hline $1956-60$ & $\ldots$ & - & 12 & 0.72 & 12 & 1.73 \\
\hline $1961-66$ & $\ldots$ & - & 6 & 0.65 & 13 & 1.43 \\
\hline
\end{tabular}

Thus the general range of the positive scarcity margins in the case of both fair price and actual price rise are as high as 30-50 per cent above landed costs except for the period 1959/60, when the margin for "fair price" went up as high as 73 per cent above the landed costs. In many cases, ex-factory prices are below landed costs, about 25-30 per cent below landed costs.

The scarcity margins widely vary as between different commodities as is evident from the coefficient of variation of the ratios of ex-factory actual prices to landed costs for individual commodities. 


\section{TABLE VI}

\section{COEFFICIENT OF VARIATION OF RATIO OF EX-FACTORY ACTUAL PRICE TO LANDED COSTS}

\begin{tabular}{llllll}
\hline & & & & A & B \\
\hline $1951-55$ & $\ldots$ & $\ldots$ & $\ldots$ & 0.17 & 0.96 \\
$1956-60$ & $\ldots$ & $\ldots$ & $\ldots$ & 0.81 & 0.56 \\
$1961-66$ & $\ldots$ & $\ldots$ & $\ldots$ & 1.51 & 0 \\
\hline
\end{tabular}

Notes: $\mathbf{A}$ indicates the coefficient of variation for the ratios below one.

$B$ indicates the coefficient of variation for the ratios above one.

As between different classes of commodities, in terms of actual ex-factory price, the highest scarcity margin is in the category of consumer goods whereas in terms of fair price, capital goods have the highest margins. In both cases, consumer goods have the largest number of items with negative margins as seen below:

\section{TABLE VII}

RATIO OF EX-FACTORY PRICE TO LANDED COST

\begin{tabular}{|c|c|c|c|c|c|}
\hline & & \multicolumn{2}{|c|}{$\underset{1951-66}{\text { Fair }}$} & \multicolumn{2}{|c|}{$\begin{array}{c}\text { Actual } \\
1951-66\end{array}$} \\
\hline & & Below one & Above one & Below one & Above one \\
\hline Consumer goods & $\ldots$ & $\begin{array}{l}0.72 \\
(23)\end{array}$ & $\begin{array}{l}1.32 \\
(26)\end{array}$ & $\begin{array}{l}0.67 \\
(38)\end{array}$ & $\begin{array}{l}1.53 \\
(35)\end{array}$ \\
\hline Intermediate goods & $\ldots$ & $\begin{array}{r}0.89 \\
(3)\end{array}$ & $\begin{array}{l}1.39 \\
(12)\end{array}$ & $\begin{array}{l}0.74 \\
(17)\end{array}$ & $\begin{array}{l}1.43 \\
(75)\end{array}$ \\
\hline Capital goods & $\cdots$ & $\begin{array}{l}0.78 \\
\text { (i5) }\end{array}$ & $\begin{array}{l}1.69 \\
(27)\end{array}$ & $\begin{array}{l}0.87 \\
(22)\end{array}$ & $\begin{array}{l}1.39 \\
(59)\end{array}$ \\
\hline
\end{tabular}

\section{COMPARATIVE COSTS AND INFANT INDUSTRY}

In a young industrialising economy, infant industries start out with high costs which, with the acquisition of skill and experience in terms of management and technical knowledge, are expected to decline over the years. Accordingly, cost ratios may be related to the age of the individual industries. It may be argued that an older industry, irrespective of its nature, benefits more from the growth of external economies and an industrial milieu. The cost ratios of the different industries on the basis of the number of years of their operation can be combined in a few limited number of broad groups as follows: 


\section{TABLE VIII}

\begin{tabular}{|c|c|c|c|c|}
\hline \multirow{2}{*}{ No. of firms } & \multirow{2}{*}{ No. of products } & \multirow{2}{*}{$\begin{array}{c}\text { No. of years in } \\
\text { operation }\end{array}$} & \multicolumn{2}{|c|}{ Comparative cost ratios } \\
\hline & & & Unweighted & Weighted \\
\hline 41 & 131 & $1-5$ & 1.54 & 1.61 \\
\hline 25 & 112 & $6-10$ & 1.61 & 1.65 \\
\hline 23 & 49 & $11-20$ & 1.46 & 1.61 \\
\hline 2 & 4 & $21-30$ & 1.34 & 1.34 \\
\hline 2 & 12 & 31 and above & 1.61 & 1.83 \\
\hline
\end{tabular}

There does not appear to be any clear relationship between length of life and comparative cost ratios. However, the data presented above do not provide an adequate test of the hypothesis partly because the composition of industries in different age groups is different and partly because the number of industries which have operated for a longer period, i.e., above 20 years or so, is very small. Conceivably, different industries have different periods of infancy and some develop competitive efficiency earlier than others. But in the above sample, various industries with widely different characteristics are lumped together for each age group. Table IX below indicates the cost ratios by the three broad categories of industries, i.e., consumer goods, intermediate goods and capital goods as well as by the number of years in operation ${ }^{8}$.

\section{TABLE IX}

\begin{tabular}{|c|c|c|c|c|c|c|}
\hline \multirow{3}{*}{ Industry } & & \multicolumn{5}{|c|}{ Number of years in operation } \\
\hline & & $1-5$ & $6-10$ & $11-20$ & $21--30$ & 31 and above \\
\hline & & & \multicolumn{4}{|c|}{ Cost ratios } \\
\hline Consumer goods & $\ldots$ & $\begin{array}{l}1.37 \\
(12)\end{array}$ & $\begin{array}{l}1.64 \\
\text { (14) }\end{array}$ & $\begin{array}{l}1.25 \\
(10)\end{array}$ & $\begin{array}{r}1.11 \\
(1)\end{array}$ & $\begin{array}{r}1.33 \\
(1)\end{array}$ \\
\hline Intermediate goods & $\ldots$ & $\begin{array}{l}1.64 \\
(19)\end{array}$ & $\begin{array}{r}1.83 \\
(3)\end{array}$ & $\begin{array}{r}1.73 \\
(6)\end{array}$ & - & - \\
\hline Capital goods & $\ldots$ & $\begin{array}{l}1.82 \\
(10)\end{array}$ & $\begin{array}{r}1.61 \\
(8)\end{array}$ & $\begin{array}{r}1.84 \\
(7)\end{array}$ & $\begin{array}{r}1.57 \\
(1)\end{array}$ & $\begin{array}{r}1.88 \\
\text { (1) }\end{array}$ \\
\hline
\end{tabular}

A more detailed classification of industries is given in Table X.

8 The cost ratios are weighted cost ratios, wieghts being the number of products .The figures in brackets of Table IX indicate the number of firms relevant to each period. 


\section{TABLE X}

\section{COST RATIOS OF MAJOR GROUPS OF INDUSTRIES AND NUMBER OF YEARS IN OPERATION}

\begin{tabular}{|c|c|c|c|c|c|c|}
\hline \multirow{2}{*}{ Industry } & & \multicolumn{5}{|c|}{ Number of years in operation } \\
\hline & & $1-5$ & $6-10$ & $11-20$ & $21-30$ & 31 and above \\
\hline Canning \& preserving & $\ldots$ & 1.41 & 1.42 & - & - & $一$ \\
\hline Bakery products & $\ldots$ & 1.19 & 1.23 & 0.67 & - & 一 \\
\hline Alcoholic beverages & $\ldots$ & - & - & - & - & 1.33 \\
\hline Footwear & $\ldots$ & 1.44 & - & 1.63 & - & - \\
\hline \multicolumn{2}{|c|}{ Paints, varnishes \& polishes } & 1.55 & 1.47 & - & 一 & - \\
\hline Matches & $\ldots$ & - & - & 0.96 & -- & - \\
\hline Pharmaceuticals & $\cdots$ & 2.67 & 1.89 & - & - & - \\
\hline Industrial chemicals & $\ldots$ & 2.71 & 一 & - & - & - \\
\hline \multicolumn{2}{|c|}{ Rubber and rubber products } & 1.78 & - & 1.75 & - & - \\
\hline Petroleum products & $\ldots$ & - & - & 1.40 & - & - \\
\hline $\begin{array}{l}\text { Non-metallic mineral } \\
\text { products }\end{array}$ & $\ldots$ & 1.64 & 1.13 & 1.25 & 一 & - \\
\hline Basic metals & $\ldots$ & - & - & 1.00 & - & - \\
\hline Metal products $\ldots$ & $\ldots$ & 1.51 & 1.67 & 2.07 & 1.11 & - \\
\hline \multicolumn{2}{|l|}{ Non-electrical machinery } & - & 1.46 & - & 1.57 & 1.88 \\
\hline Electrical machinery & $\ldots$ & 2.63 & 1.62 & 1.69 & - & - \\
\hline Transport equipment & $\ldots$ & 1.31 & 1.23 & - & - & - \\
\hline Plastic products & $\ldots$ & 1.13 & 1.95 & 一 & - & - \\
\hline Paper \& paper products & $\ldots$ & - & $一$ & 1.32 & - & 一 \\
\hline Made-up textiles & $\ldots$ & 1.40 & 0.68 & - & - & - \\
\hline \multicolumn{2}{|c|}{ Miscellaneous manufacturing } & - & 1.59 & 1.42 & - & - \\
\hline
\end{tabular}

The sample of industries in the last two age groups is too small to permit any comparison. Even comparison among the last three age groups does not yield any consistent and systematic behaviour of the cost ratios with increasing years in operation. In some cases, such as the total of the consumer goods or intermediate goods industries, the ratios first increase and then decrease with increasing years of operation; in the case of the capital goods industries, they go down first and then go up. The time pattern of the behaviour of the cost ratios of the individual industries is not very different as is shown in Table XIII. If 
one compares the first and third age groups only the cost ratios in the case of such industries as bakery products, paints, varnishes and polishes, pharmaceuticals, rubber and rubber products, non-metallic mineral products, electrical machinery, transport equipment, made-up textiles and miscellaneous industries, register a decline. This is not true for the rest of the industries, some of which suffer a rise in cost ratios with an increase in the number of years in operation.

The above analysis, therefore, does not appear to provide any satisfactory or conclusive answer to the problems of the behaviour of the cost ratios over time. Partly these comparisons are constrained because each industry group combines a large variety of products and activities whose cost behaviour over time may widely differ. An earlier analysis of the fifteen specific industries for which the cost ratios were reviewed by the Tariff Commission indicated an improvement in comparative efficiency in the course of ten to fifteen years, They covered about forty individual products. For seven industries and sixteen products the cost ratios declined by 25 per cent to 60 per cent. The rest of the cost ratios declined by 5 per cent to 24 per cent [4, Table 3, p. 11].

An analysis of the cost ratios over time by itself may not provide an adequate test of the infant industry hypothesis. The cost ratios may turn unfavourable, even when there is an improvement in efficiency and productivity in the.domestic industry because the costs of competing imports may fall faster as a result of a more rapid technological progress in the advanced countries. The problem is then one of the speed of technological advance in developed countries and a lag in the developing countries in the process of their "catching up". This suggests that a more detailed analysis of the changes in the productive efficiency of the domestic industries over time is necessary; this necessitates an identification of the changes in costs which are not due to $a$ ) changes in wage rates, $b$ ) profits, and $c$ ) input prices over time, since it is an improvement in efficiency in the use of inputs through a learning process, as distinct from technological advance, that is involved in the infant industry argument. The improvement in efficiency in this sense should be compared with the cif prices which would have prevailed in the absence of technological advance. The statistical testing of a comparative cost analysis in a dynamic context of technological change thus confronts formidable difficulties.

\section{COMPARATIVE COSTS AND OVERVALUATION OF EXCHANGE}

The comparative cost ratios in the preceding paragraphs have been obtained on the basis of the official exchange rate. To the extent that the Pakistani currency is overvalued, of which there is some evidence, comparative cost ratios greater than one really reflect the overvaluation of currency so that with an equilibrium rate of exchange the cost ratios all will be equal to each other and equal to one. 
The Pakistani rupee was devalued in 1955 and the fall in the average cost ratio between the periods, i.e., 1951-55 and 1956-60 may be partly traced to this fact, since with devaluation the cif price of imports in rupee went up.

One may, therefore, suggest that the comparative cost ratios should be corrected for the relative overvaluation of the currency. The study on the domestic prices of imports as well as analysis of the amount of subsidy implicit in the export bonus scheme tends to suggest that the assumption of a 50 per cent overvaluation in the price of foreign exchange in Pakistan may be reasonable one. It is not easy to estimate what would be the equilibrium rate of exchange in a free market with existing tariffs and domestic fiscal and monetary policies; supply and demand elasticities of exports and imports as well as that of demand and supply of domestic substitutes, etc., enter into picture in a complicated way. The assumption of 50 per cent overvaluation may not be far out of line for use as an illustration. The adjustment in the comparative costs ratio for alternative estimates of overvaluation of exchange is easily done.

As a result of the correction for the overvaluation of exchange, the comparative cost disadvantage declines and the number of industries which have cost ratios below one and, therefore, are competitive are as follows:

\section{TABLE XI}

\begin{tabular}{llcccc} 
Cost ratios & & \multicolumn{5}{c}{ Number of industries } & \\
& & $1951-55$ & $1956-60$ & $1961-66$ & Total \\
\hline Below one & $\ldots$ & $17(0.84)$ & $14(0.73)$ & $26(0.83)$ & 57 \\
Above one & $\ldots$ & $12(1.33)$ & $10(1.27)$ & $36(1.50)$ & 58 \\
\hline
\end{tabular}

For the period as a whole about half of the total number of industries appear to be competitive with imports while the other half have a higher cost ratio. The overall weighted cost ratios for the three periods after adjustment for the price of foreign exchange are 1.08 for 1951-55, 1.08 for 1956-60 and 1.21 for 1961-66. The weighted ratios for different groups of industries for the whole period are as follows:

$\begin{array}{lllll}\text { Consumer goods } & \ldots & \ldots & \ldots & 1.03 \\ \text { Intermediate goods } & \ldots & \ldots & 1.24 \\ \text { Capital goods } \quad \ldots & \ldots & \ldots & 1.19\end{array}$

The consumer goods industries appear competitive whereas the capital goods industry is 19 per cent more expensive and intermediate goods industry 24 per cent more expensive than the competing imports. 
The correction of the cost ratios for the relative overvaluation of the currency, as shown above, is only partial in so far as it corrects the cif price of the competing imports in domestic currency and does not correct the import component of the domestic ex-factory price in domestic currency. The import component becomes more expensive in terms of domestic currency consequent on a correction for the overvaluation of foreign exchange. The data on the foreign exchange component of all the products are not available. In the case of only twenty-nine industries and their corresponding one hundred and seven products, the foreign exchange component (current requirements of imported raw materials and spare parts) is available and the result of adjustment for the value of foreign exchange is given below:

\section{TABLE XII}

COST RATIOS ADJUSTED FOR OVERVALUATION OF EXCHANGE RATE

Unadjusted

2.29

1.82

1.79

1.86
Adjusted

1.66

1.53

Intermediate goods

Capital goods

Total:
1.45

1.33

1.44
Adjusted only for cif price

Thus the cost ratio for all industries decline from 1.86 to 1.44 , i.e., about 23 per cent. It is important to mention that after either adjustment for the value of foreign exchange, the ranking of the twenty-nine or three broad categories of industries does not change either in terms of the ex-factory price, or the foreign exchange component of the ex-factory price, or the comparative cost ratios.

\section{PROFITS, MARKET STRUCTURE AND EXCESS CAPACITY}

One important aspect of the analysis of comparative cost ratios on the basis of ex-factory price is the extent to which the high ex-factory prices may be due to high profits or high factor prices in the relevant industries. If the factor costs do not represent scarcity prices but contain large monopoly or rent elements due to the institutional factors and the imperfections of markets, the high ex-factory price is not an index of comparative disadvantage or inefficiency but represents a transfer from the rest of the community to the factors employed in the industries concerned. The industrial wage for unskilled worker is generally presumed to be higher than the agricultural wage by more than what is accounted for by the costs of movement. Again, wage rate is higher in organised industries than in unorganised, small scale industries. Even larger firms in the 
same industry are found to pay higher wage rates than the smaller firms. One could argue that the kinds of labour employed in large and small scale industries or in large and small firms in the same industry are sufficiently different in terms of work, discipline and ability to account for the wage differentials. These are issues on which conclusive answers are neither available nor can they be dealt with within the purview of the present paper. There is some evidence, however, which permits at least a partial examination of how far excess profits may have contributed to the high ex-factory price.

The cost ratios discussed earlier include mostly actual ex-factory prices which include abnormal profits, if any. In some cases, actual prices are not available and hence "fair" prices are used for estimating the comparative cost ratios. The 'fair' prices, barring adjustments in a few cases for selling, distribution and overhead expenses, which are considered exorbitant by the Tariff Commission, are different from the actual prices in so far as the latter incorporate abnormal profits. The concept of normal profits expressed in terms of "mark-up" over the cost of production which the Commission considers fair and reasonable has varied over the years. There are indications, however, in a number of reports that the mark-up permissible has increased over the years. In so far as the actual percentage of profit on invested capital which is allowed by the Commission in its estimation of fair price is concerned, it is not always mentioned in its earlier reports. During the fifties, the percentage of profit allowed on invested capital appears to be in the neighbourhood of 10 per cent in those cases where such a mention has been made, whereas in the sixties, when the reference to the rate of profit is more frequent, it has increased by gradual stages over the years to $12 \frac{1}{2}$ per cent (1963), 15 per cent (1964), 19 per cent (1965), and 20 per cent (1966).

There are about 39 industries for which data on both fair and actual prices are available; they indicate the prevalence of abnormal profits in the sense that in these industries the actual prices are higher than the fair prices to an extent varying between 8 per cent and 32 per cent $[4$, Table 7, p. 24]. A few have been found to be suffering losses. It is pertinent to point out, however, that abnormal profits earned by the firms under consideration may in fact be larger than what is reported, and reported losses may be misleading in so far as the firms succeed in either misreporting their costs or, in the case of direct investigations by the Commission, succeed in avoiding a careful scrutiny of the detailed cost data. The valuation of the fixed assets on the basis of which the individual industries fix their actual rate of profit or the Commission fixes its fair rate of profit is in any case not an easy exercise. Thus the comparative cost ratios given below based on fair ex-factory prices may still contain elements of excess profits which 
are not related to the comparative efficiency of the industries concerned with the result that the fair cost ratios may indeed be lower than what is indicated below:

\section{TABLE XIII}

COMPARATIVE COST RATIOS 9

\begin{tabular}{|c|c|c|c|c|c|c|c|c|}
\hline & \multicolumn{2}{|c|}{$1951-55$} & \multicolumn{2}{|c|}{$1956-60$} & \multicolumn{2}{|c|}{$1961-66$} & \multicolumn{2}{|c|}{$1951-66^{\circ}$} \\
\hline & Actual & Fair & Actual & Fair & Actual & Fair & Actual & Fair \\
\hline Consumer goods & $\begin{array}{c}1.39 \\
(19)\end{array}$ & $\begin{array}{l}1.53 \\
(36)\end{array}$ & $\begin{array}{l}1.25 \\
(15)\end{array}$ & $\begin{array}{l}1.62 \\
(10)\end{array}$ & $\begin{array}{l}1.83 \\
(45)\end{array}$ & $\begin{array}{r}1.48 \\
(11)\end{array}$ & $\begin{array}{l}1.62 \\
(79)\end{array}$ & $\begin{array}{l}1.30 \\
(67)\end{array}$ \\
\hline Intermediate goods & $\begin{array}{r}2.39 \\
(2)\end{array}$ & 1.19 & $\begin{array}{r}1.91 \\
(2)\end{array}$ & $\begin{array}{c}1.10 \\
(2)\end{array}$ & $\begin{array}{l}1.88 \\
(82)\end{array}$ & $\begin{array}{l}1.68 \\
(76)\end{array}$ & $\begin{array}{l}1.89 \\
(86)\end{array}$ & $\begin{array}{l}1.65 \\
(81)\end{array}$ \\
\hline Capita goods & $\begin{array}{r}2.24 \\
(12)\end{array}$ & $\begin{array}{l}1.60 \\
(27)\end{array}$ & $\begin{array}{l}1.67 \\
(30)\end{array}$ & $\begin{array}{l}1.96 \\
(14)\end{array}$ & $\begin{array}{l}1.82 \\
(34)\end{array}$ & $\begin{array}{l}1.66 \\
(12)\end{array}$ & $\begin{array}{l}1.82 \\
(76)\end{array}$ & $\begin{array}{l}1.70 \\
(53)\end{array}$ \\
\hline All goods: & $\ldots 1.76$ & 1.61 & 1.55 & 1.76 & 1.85 & 1.66 & 1.78 & 1.62 \\
\hline
\end{tabular}

The comparative cost ratios on the basis of fair ex-factory price are generally lower than those based on actual ex-factory price. The fair cost ratio in some instances, specially during the periods $1951-55$ and 1956-60, is higher than the actual ratio. In some of these latter cases, of course, the firms may be making losses or the two sets of ratios may relate to the different commodities. During 1961-66, the sample of industries covered under each set of ratios is much larger and the commodities covered in the two types of ratios are more comparable. Over the whole period 1951-66, the fair cost ratio is consistently below the actual cost ratio for all the three categories.

If allowance is made for the fact that actual profits as reported by the Tariff Commission probably underestimate "true" profits, the fair cost ratio, excluding excess profits, both recorded and unrecorded, would be even lower. The existence of very large profit margins, larger than 10-12 per cent over the cost of production and larger than 12-20 per cent over capital investment is also indicated by the additional evidence which is available on the profitability of industrial enterprises in Pakistan. A recent study of the balance sheets of public limited companies, which are listed in the stock exchange, shows that between 1959 and 1963 gross profits as a percentage of capital employed varied between 14 and 15 per cent. This was during the period when normal profits as allowed by the Commission varied between $10-12$ per cent [7]. This is also a very partial evidence and possibly is an underestimate. 
Thus if allowance is made for $a$ ) excess profits (to the extent of 10 per cent) and $b$ ) scarcity price of foreign exchange or the overvaluation of exchange rate, (to the extent of 50 per cent) the aggregate comparative cost ratio is considerably reduced. Thus the cost ratio will be reduced by a factor of 65 per cent, i.e., all the products with the cost ratios which are 1.65 and below will become competitive with the foreign product $\left[7\right.$, p. 21] ${ }^{10}$. The number of industries and products which have cost ratios below 1.50 and below 1.65 are given below. This generally indicates the change in the proportion of industries which become competitive when proper adjustments are made for the above two factors.

\section{TABLE XIV}

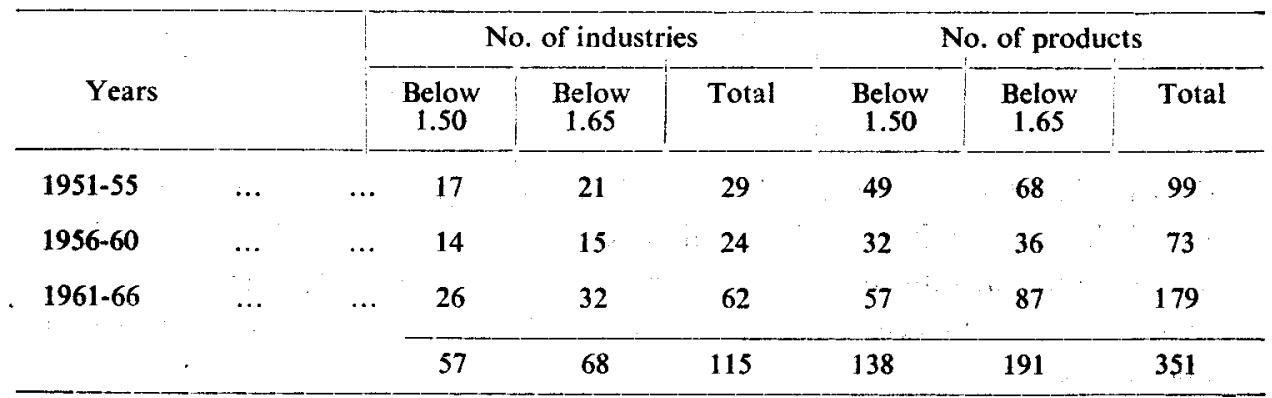

It appears that between 50 to 60 per cent of industries and between 40 to 54 per cent of the products become competitive as against about 10 per cent of the industries and 5 per cent of the products which are competitive in the absence of such adjustments.

An important question is to what extent the ranking of industries is affected by either an adjustment of foreign exchange or an adjustment for excess profits. A rank correlation between fair and actual price is found to be very high, i.e., 0.68 and it is significant at 5 per cent level. Similarly, the ranking of industries is undisturbed if cost ratios are adjusted for the overvaluation of foreign exchange. The rank correlation coefficient between unadjusted cost ratios and cost ratios adjusted for the overvaluation of exchange is very high, i.e., 0.96 and is highly significant at the 5 per cent level of significance.

The cost ratios may also be affected by the existence of excess capacity or a structure of market where few firms dominate. There is a considerable excess capacity in the manufacturing industries in Pakistan. About 60 per cent of the

10 This estimate, however, does not make any adjustment for the foreign exchange component of the domestic product which has the effect of raising the cost ratio. Making this double adjustment for overvaluation, where permitted by the data, would reduce the cost disadvantage by 23 per cent, and then all industries with cost ratios of 1.33 and below would be made competitive. 
industries examined worked below 40 per cent of their installed capacity. The prevalence of excess capacity is not significantly different between the three categories of industries as is shown below ${ }^{11}$.

TABLE XV

UTILISATION OF CAPACITY IN MANUFACTURING INDUSTRIES

\begin{tabular}{|c|c|c|c|c|c|}
\hline \multicolumn{2}{|c|}{$\begin{array}{c}\text { Percentage of capacity } \\
\text { utilisation }\end{array}$} & & Consumer goods & Intermediate goods & Capital goods \\
\hline & & & \multicolumn{3}{|c|}{ (percentage of total number of industries in each group) } \\
\hline $0-20$ & $\ldots$ & $\ldots$ & 27.60 & 34.80 & 11.10 \\
\hline $20-40$ & $\ldots$ & $\ldots$ & 34.50 & 43.50 & 38.90 \\
\hline $40-60$ & $\cdots$ & $\ldots$ & 10.30 & 17.40 & 22.20 \\
\hline $60-80$ & $\ldots$ & $\ldots$ & 10.30 & - & 22.20 \\
\hline $80-100$ & $\ldots$ & $\cdots$ & 17.30 & 4.30 & 5.60 \\
\hline
\end{tabular}

Most of the industries have only a few firms. In many instances the number of firms is larger than justified by the limited extent of the domestic market. Since each produces at substantial excess capacity, a reduction in the number of firms would enable a concentration of output in a fewer firms, each producing at a fuller capacity.

The shortage of imported raw materials has been suggested as an important factor in explaining the existence of excess capacity. An attempt is made to see whether more import intensive industries suffer from a greater excess capacity. No strong correlation is discernible. This is plausible in view of the licensing procedure under which the licensing is a function of the assessed import requirements and there may be in fact a bias towards a more liberal licensing for the import intensive industries, specially if they are successful in the export markets. An analysis of excess capacity and reasons thereof, as well as the opportunities of cost reduction consequent on the utilisation of capacity, in the industries under investigation has already been pointed out 12 .

To what extent are high cost ratios due to the prevalence of excess capacity? While there is evidence that the cost of production declines with a greater utilisation of capacity, it is difficult to quantify the reduction in costs in the absence of additional data. Moreover, even if costs decline consequent on a greater utilisation of capacity, the behaviour of prices depends upon what happens in the

11 Excess capacity is defined as the difference between the actual output and the installed capacity as assessed by the technical investigations of the Tariff Commission. The number of shifts implied in the assessment of installed capacity is not clearly indicated. The observations relating to excess capacity relate to different industries in different points of time.

12 [4, pp. 25-26]. The ex-factory price of fifteen industries may be reduced anywhere between 8 per cent and 25 per cent depending upon the nature of the industry. 
meanwhile to a number of factors such as changes in demand and factor prices. It also depends upon the pricing policy of the industry, i.e., whether it maximises profits or not, and upon whether the crucial limitation on the expansion of output is the limited market or the shortage of inputs.

The above argument relates to the price behaviour or changes in the comparative cost ratio of a given product under a changing utilisation of capacity. Whether the differences in the comparative cost and price ratios of different industries are related to the differences in the degree of utilisation of capacity is another matter and raises additional questions. The differences in the cost ratios between different industries is only partly a matter of differences in the utilisation of capacity. An industry may operate at a smaller capacity than another but may still have lower cost ratio because it is more efficient in the use of its inputs even at a lower level of operations than the other at a higher level vis-a-vis its competing imports. Its managerial and technical efficiency may be higher; prices of the factors necessary in its operation may be lower, and taxes on its inputs may be lower to offset the disadvantages of lower scale of operations. Thus an attempt to explore the correlation between cost ratios and percentages of capacity utilisation does not indicate any significant results. Nor do the profit rates $(P)$ seem to be related to the number of firms $(\mathrm{N})$ as is seen below ${ }^{13}$ :

$$
\begin{gathered}
P=-0.096-0.00098 \mathrm{~N}+0.0228 \mathrm{~T} \\
(0.00083) \quad(0.021) \\
\mathrm{R}^{2}=0.56
\end{gathered}
$$

The excess profit $P$ is defined as the difference between actual and normal price expressed as a ratio of actual price 14 . $T$ stands for a dummy variable which is taken to be zero for all values of $\mathbf{P}$ which are negative (losses) and one for all values of $P$ which are positive. The correlation is not significant and without the dummy variable $T$, the relationship is still not significant as is below:

$$
\mathrm{P}=0.035+0.0007 \mathrm{~N}
$$

$$
\mathrm{R}^{2}=0.0033
$$

The relationship between excess profit $(P)$ and capacity utilisation $(W)$ is as follows:

$$
\begin{gathered}
P=-0.088-0.00079 \mathrm{~W}+0.204 \mathrm{~T} \\
(0.00063) \quad(0.023) \\
\mathrm{R}^{2}=0.57
\end{gathered}
$$

13 All the regression equations in the present study are as "weighted" equations in the sense that each variable is given a weight equal to the number of products it relates to.

14 Excess profit is used here in the sense of abnormal markup or the excess over the "normal" or fair markup on ex-factory price as used by the Tariff Commission. 
where $T$ is a dummy variable as explained above but without $T$, the relationship is statistically significant.

$$
\begin{array}{r}
P=0.104-0.0029 \mathrm{~W} \\
(0.00081) \\
\mathrm{R}^{2}=0.14
\end{array}
$$

Excess profit seems to be negatively related with capacity utilisation. That is, the greater the utilisation of capacity, the lower is the excess profit as a percentage of actual ex-factory price. With a larger output, the firms tend to charge a lower profit margin since a lower profit margin on a larger output, may still lead to large absolute profits and more important, to a higher return on capital. But the magnitude of the fall in excess profit in response to a given change or increase in the utilisation of excess capacity is very small, as is seen from the small magnitude of the correlation coefficient between excess profit and capacity utilisation.

\section{COMPARATIVE COSTS AND FACTOR PROPORTIONS}

There is a considerable diversity in the comparative costs of different industries as analysed above. A relevant question is whether the comparative costs of different industries can be related to and explained by the diversity in the characteristics of these industries in respect of technology and factor proportions. It is expected that in a labour abundant country like Pakistan more labourintensive industries are likely to have lower cost ratios compared with the less labour-intensive industries. Data on labour costs as a proportion of ex-factory price are not available for all the industries under investigation. For a number of industries data are available on direct labour costs and not on indirect labour costs which are part of the overhead cost, i.e., administrative as well as selling and distribution expenses 15 . The regression equation relating the comparative cost ratios (Y) to the direct labour cost ratios $(\mathrm{L})$ is shown below:

$$
\begin{gathered}
\mathrm{Y}=2.02-2.47 \mathrm{~L} \\
(2.11) \\
\mathrm{R}^{2}=0.019 \\
\log \mathrm{Y}=0.252-0.154 \log \mathrm{L} \\
(0.032) \\
\mathrm{R}^{2}=0.18
\end{gathered}
$$

15 [8]. In this exercise the comparative cost ratios and the labour cost ratios of the individual products are not combined to arrive at the average ratios for each industry. This increases the number of observations which are conducive to a satisfactory statistical testing. There are differences, often significant, between the labour cost ratios of individual products in a given industry. 
The double logarithmic regression gives reliable regression coefficients. The correlation is not very high but the regression coefficient is negative and statistically significant at 5 per cent level, implying a reliable relationship between variations in the labour cost ratio and in the comparative cost ratio. A 10 per cent increase in labour cost ratio causes a decline in the comparative cost ratio to the extent of 1.5 per cent.

Attempts to correlate the comparative cost ratios to the capital-output ratios are limited by a lack of direct data on the capital-output ratios of the specific industries under investigation. The Censuses of Manufacturing Industries in Pakistan provide data on the fixed assets, employment and wages and salaries by the major groups of industries. The comparative cost ratios which relate to specific individual industries may be grouped according to the classification of the major industry groups in the census. The capital-output ratios of the major groups of industries are then related to the cost ratios of the groups of industries 16 . The capital/output ratios are available for $1959 / 60$ and 1955 . The former is related to the cost ratios for the period 1961-66, and 1956-60 and the latter to the period 1951-55, respectively. The regression equations relating the cost ratios $(\mathrm{Y})$ to the capital-output ratios $(\mathrm{K})$ are given below:

$$
\begin{aligned}
& \log \mathrm{Y}=0.078+0.003 \log \mathrm{K} \quad(1951-55) \\
& \text { (0.049) } \\
& \mathbf{R}^{2}=0.0038 \\
& \log \mathrm{Y}=0.195+0.021 \log \mathrm{K} \\
& (0.075) \\
& \mathrm{R}^{2}=0.0092 \\
& \log Y=-1.175+0.704 \log K \\
& \text { (0.0207) } \\
& \mathrm{R}^{2}=0.87
\end{aligned}
$$


The cost ratios and the capital-output ratios are positively correlated for the period (1961-66) and the correlation is highly significant. The higher the capitaloutput ratio of an industry, the higher is its comparative cost ratio. The magnitude of the relationship is also high implying a 7 per cent rise in cost ratio in response to a 10 per cent rise in capital-output ratio. However, for the other two periods, i.e., 1956-60 and 1951-55, the retationship between cost ratio and capitaloutput ratio, though positive is not significant. The simple linear relationships are less reliable than what is shown in the above logarithmic equations.

The above two exercises relating the cost ratios to the labour cost-output ratio and the capital-output ratio as possible explanations of the variability in the cost ratios between industries, tend to indicate that the industries which use more labour per unit of output and less capital per unit of output are more advantageously placed in respect of their comparative efficiency. Admittedly the evidence on the effects of differences in the capital-outout ratio is not very conclusive firstly because, in two of the three periods for which the hypothesis is tested, the regression coefficients are not significant and also because of the general limitations of the data on which the exercise is based.

A low capital-output ratio is consistent with a high capital-labour ratio. A more capital intensive product (a higher proportion of capital to labour) may result in a low capital-output ratio if capital is very productive in the sense that it raises the productivity of labour more than the increase in capital intensity. An attempt is made to relate the comparative cost ratios to the skill and capital intensities of the industries, i.e., the relative proportion of skilled to unskilled labour and the proportion of capital to labour. Under the simplest of assumptions one can hypothesise that the higher the ratio of wages and salaries per employee, the higher is the proportion of non-wage value added per employee, the higher is the proportion of capital to labour. This assumes that the differences in wage rate per employee between industries are entirely due to the differences in skill and the labour of the same skill receives the same wage in different industries. Similarly, the assumption involved in treating the non-wage value added per employee as an index of a higher capital-labour ratio is that the return on capital is the same irrespective of the variation in the amount of capital used, and that the return on capital is the same as between different industries. Under constant returns to scale and perfectly competitive conditions, this is a correct assumption. The results of the following exercise have to be viewed in the context of the restrictive nature of the above assumptions.

In the following analysis a) the wage and salaries per employee (T) and $b$ ) non-wage value added per employee (S) are related to the comparative cost ratios 
(Y) of different industries ${ }^{17}$. In all the periods the simple linear relationships do not yield reliable results ${ }^{18}$. The double logrithmic relationships yield reliable results for all the periods except for wages and salaries per employee in $1961-66$ as is seen below:

1951-55

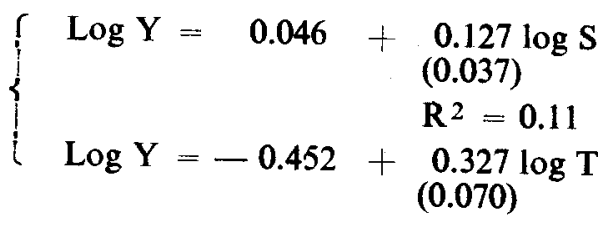

1956-60

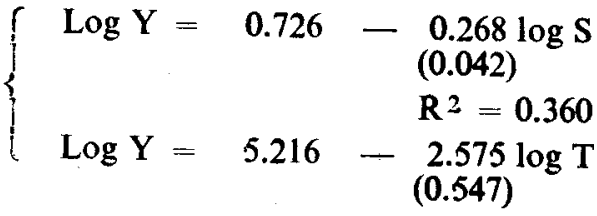

1961-66

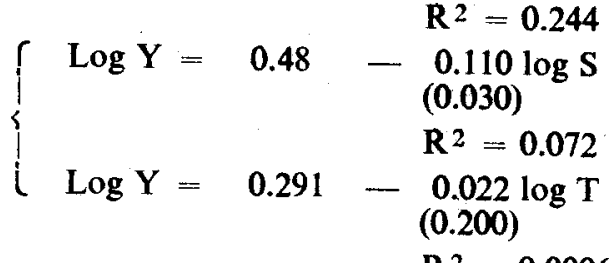

17 [10 and 11]. The data on non-wage value added is subject to error in the sense that it includes $a$ ) depreciation allowances, $b$ ) rent, and $c$ ) some miscellaneous expenses. As in the case of the exercise on capital-output ratios, these two ratios for the major groups of industries are obtained from the Censuses of Manufacturing Industries are related to the combined comparative cost ratios of industries which fall in the same group but which in some cases cover only a small fragment of the major industry group or cover only a few selected individual industries. Moreover, the value added (wage and non-wage) ratios for 1955 are related to the cost ratios for the period 1951-55 and those for 1959/60 are related to the cost ratios of 1956-60

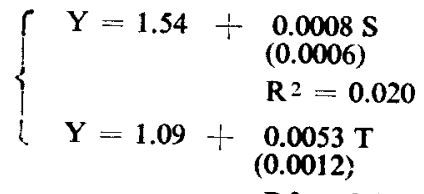

1956-60

$$
\mathbf{R}^{2}=0.15
$$

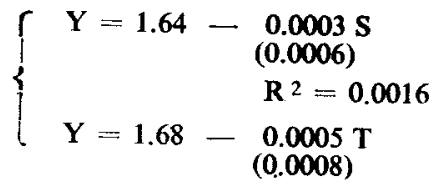

1961-66

$$
\mathbf{R}^{2}=0.0053
$$

$$
\left\{\begin{array}{cc}
\mathrm{Y}=1.93- & 0.0008 \mathrm{~S} \\
& (0.0004) \\
& \mathrm{R}^{2}=0.0185 \\
\mathrm{Y}=1.92- & 0.0009 \mathrm{~T} \\
(0.0013) \\
\mathrm{R}^{2}=0.0020
\end{array}\right.
$$


The regression coefficients except for $T$ in 1961-66 are all significant at the 5 per cent level. But the results for 1956-60 and 1961-66 contradict those for the period 1951-55. The data for 1951-55 indicate that the more skill intensive and capital intensive industries have higher cost ratios whereas the data for 1956-60 and 1961-66 indicate the reverse. The strength of the relationship in all the cases as indicated by the correlation coefficient is very small,i.e., the coefficient of determination varies between 0.11 and 0.18 in $1951-55$ and between 0.36 and 0.24 in 1956-60 and is 0.072 in 1961-66. Therefore, a very small proportion of the variance or the variations in the inter-industry comparative cost ratios are explained by the variations in factor proportions in the sense defined here.

A more appropriate relationship to explain interindustry variations in the comparative cost ratios would be a joint or multiple relationship between the cost ratios and the differences in skill and capital intensities between the individual industries. A simple correlation does not reveal the joint influence on the comparative cost ratios and may even yield biased results. A multiple correlation yields a better result in terms of the explanation of the variance or the interindustry variations in the cost ratios as given below:

$1951-55$

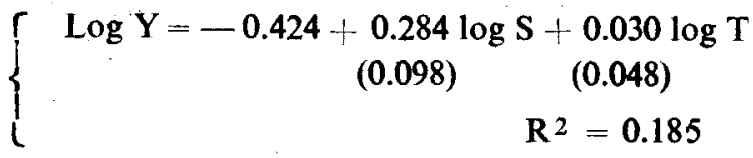

956-60 $\left\{\begin{array}{r}\log Y=-0.356-0.415 \log S+0.679 \log T \\ (0.045) \\ (0.127) \\ R^{2}=0.548\end{array}\right.$

$1961-66$

$\left\{\begin{array}{rr}\log \mathrm{Y}=-0.132-0.217 \log \mathrm{S}+ & 0.403 \log \mathrm{T} \\ (0.046) & (0.117) \\ \mathrm{R}^{2} & =0.111\end{array}\right.$

The multiple correlations yield more reliable results and provide a better explanation of the variations in cost ratios. All the multiple correlation coefficients are much larger than the simple correlation coefficients obtained earlier and are statistically significant at 5 per cent level; all the regression coefficients excepting that of $T$ (wage and salaries per employee) in 1951-55, are statistically significant at 5 per cent level. Generally speaking, the skill intensive industries as indicated by the higher wages and salaries per employee seem to have high cost ratios, except in 1951-55 when the coefficient is not reliable. This is also confirmed by one of the two simple regressions, which yield reliable results. Again, excepting in 1951-55, the capital intensive industries seem to be associated with the low cost ratios. This is also corroborated by the results of the simple regressions. 
The earlier results indicate a significant positive correlation between cost ratios and the capital-output ratios for the periods 1956-60 and 1961-66 but not for 1951-55. This is consistent with a significant negative correlation between the cost ratios and the non-wage value added per employee which is yielded by both simple and multiple correlations in two of the three periods. An increase in the non-wage value added per employee implying a higher ratio of capital to labour may lead to a high productivity of capital and thus a decline in the capital-output ratio. The evidence on the positive relationship between wages and salaries per employee and cost ratio between the time periods is less conclusive, in so far as the results of all the simple and multiple regressions are not consistent, even though multiple regressions which yield a positive relationship provide in general a better explanation of the relationships examined. While, as is seen earlier, on the one hand, a higher ratio of labour cost to output is associated with a low comparative cost ratio, higher wages and salaries per employee, on the other hand, are associated with a higher cost ratio. This would imply that skill intensive industries in the sense of a higher proportion of skilled to unskilled workers is associated with a lower ratio of labour cost to output. It is only when an increase in wages and salaries per employee is associated with a faster increase in output per employee that the labour cost per unit of output will decline with an increase in skill intensity. Thus high labour cost-output ratio is associated with a low proportion of skilled to unkilled labour. This indicates that the industries with a low skill intensity but with a high proportion of labour costs to value of output are more competitive with imports from abroad. Though more skill intensive industry have a lower labour cost per unit of output, their total costs and ex-factory prices vis-a-vis the prices of competing imports are higher than those of the less skill intensive industries. The labour cost ratio, though it does not distinguish between unskilled and skilled labour, as used in this study, includes only direct labour and excludes the managerial labour and the labour component of the overhead and distribution expenses, which may include a higher proportion of skilled labour than is included in the category of direct labour cost. Moreover, while interpreting the interindustry variations in the comparative cost ratios with reference to wage and non-wage value added per employee, it is important to note that the use of these ratios as the indices of capital and skill intensities is subject to a number of limitations which have been discussed earlier. But subject to the limitations of data and methodology, the above analysis provides some evidence, though very tentative at this stage, that the industries with a high component of skill and with high capital-output ratio tend to have high comparative cost ratios. This seems to provide a confirmation of the commonsense view that technical skill is a very scarce factor and high priced in Pakistan at our present stage of 
development. Until a wide diffusion of technical knowledge and skill takes place, consequent on increased investment in this direction, the industries which need high levels of skill will tend to suffer from high cost disadvantages in relation to competing imports. Similarly, the limited evidence on the positive correlation between the capital-output ratio and the comparative cost ratio may be attributed to the learning costs associated with the use of capital in the early stage of development.

\section{CONCLUSION}

The manufacturing industries in Pakistan suffer, on the whole, from a high cost disadvantage vis-a-vis the competing imports. The weighted average cost ratios vary between 1.50 and 1.90 , i.e., the ex-factory prices are 50 to 90 per cent higher than the cif prices. Thirty per cent of the industries examined in this study have ex-factory prices $51-100$ per cent higher than their corresponding cif prices; about 16 per cent of the industry have prices $100-200$ per cent higher than the cif prices [4, Table 2, p. 8]. This range of the comparative cost ratios compares well with those obtained from the earlier studies based on an analysis of the domestic prices of imported goods, allowing for the differences in the methodology and commodity composition of the two studies. The tariffs do not seem to provide an appropriate measure of either absolute or relative cost disadvantage of the different industries in Pakistan. On the one hand, because of quantitative restrictions, there are, positive scarcity margins over the landed costs of the competing imports for a great majority of the commodities examined here; on the other hand, there are many commodities for which the ex-factory price is below landed cost. For example, in 30 per cent of the cases, actual exfactory prices and in 40 per cent of the cases, fair ex-factory prices fell short of the landed costs. Positive scarcity margins usually vary between $30-50$ per cent except in one year when it rose to 73 per cent. In those cases in which ex-factory prices fall below the landed costs of competing imports, they are as much as 25 to 30 per cent lower.

As is well known and is further corroborated by the present analysis there is widespread underutilisation of capacity, engendered partly by a lack of coordination between industrial investment licensing and the licensing of imports of raw materials and spare parts [4, footnote 18]. Even though excess capacity contributes to high cost in a particular industry there is no evidence that interindustry differences in cost ratios are explained by the differences in excess capacity which are substantial in almost all the industries any way.

High comparative cost ratios of the Pakistani industries however, do not necessarily measure the inefficiency of industrialisation in Pakistan to an equivalent extent, if allowance is made for $a$ ) an overvaluation of exchange rate and 
b) the existence of high or excessive profits in many industries generated by a lack of competition, either internal or external, in the domestic market. An adjustment of the cif price of the competing imports as well as of the foreign exchange component of the ex-factory price, on the assumption of 50 per cent overvaluation, in the case of a sample of twenty-nine industries and one hundred and seventy products, shows that the aggregative comparative cost ratio declines from 1.84 to 1.44 , i.e., by 23 per cent. If one adjusts only the cif price and not the foreign exchange component of the ex-factory price, 50 per cent of the industries under examination become competitive. Again, if allowance is made for the fact that ex-factory price contains elements of excess profits, the comparative cost ratio will be further reduced by $10-11$ per cent. When however, both adjustments are made for overyaluation in the few cases when the data permit them to be done, the industries with the comparative cost ratio of 1.33 and below become competitive in the world market.

In so far as the growth of the infant industries into adulthood is concerned, the evidence examined in this paper on this subject is quantitatively very small. The performance of only a few industries, about fifteen in all, has been reviewed by the Tariff Commission subsequent to the grant of protection by it. The evidence indicates an improvement in comparative advantage and a decline in cost ratios; an attempt to correlate the cost ratios with the length of the period of operation of the corresponding industry groups does not provide any conclusive, systematic, and consistent evidence relating to the development of infant industries. While there are a few cases of a fall in the cost ratios with an increase in the number of years of operation and an accumulation of experience, it is not true for all nor is there any evidence that the cost ratios are a smooth and a continuously declining function of an increase in the number of years of operation. A satisfactory examination of this problem is, however, inhibited by the limitation of the data.

In so far as the differences in the comparative costs among the individual industries are concerned, the industries with a higher labour-output ratio have a greater comparative advantage. However, the gain in terms of comparative costs resulting from the choice of industries with a higher labour cost does not appear to be appreciable. At the same time industries with a high component of skilled to unskilled labour tend to have high cost ratios, though the evidence on this is not conclusive. There is some evidence that industries with a high capitaloutput ratio have also high comparative cost ratio. Contrariwise, the industries which have higher non-wage value added per employee, i.e., with a higher ratio of capital to labour, tend, however, to have lower comparative cost ratios imply: ing that with a greater application of capital to labour, productivity of capital goes up, and cost disadvantage declines. However, it is necessary to point out that these conclusions are very tentative and need to be further verified on the basis of additional, more reliable and comprehensive data and for different samples of industries and different years. 


\section{Appendix A}

\section{A COMPARISON WITH EARLIER STUDIES}

The comparative cost ratios derived above may be compared with the results of an earlier study; which estimated the domestic prices of imports; domestic prices include tariffs, other indirect taxes and scarcity margins on cif prices of the imports [4, footnote 7], as a result of quantitative restrictions on imports. On the assumption that the imported and the domestic products closely competing with them fetch the same wholesale prices in the domestic product, the ratio between the cif price and the domestic wholesale price, i.e., (wholesale price/cif price) is given below for the three main categories of commodities.

\section{TABLE A-1}

\section{COST RATIOS BASED ON DOMESTIC PRICES OF IMPORT: 1964/65}

\begin{tabular}{|c|c|c|c|c|c|c|}
\hline & \multicolumn{2}{|c|}{ Karachi } & \multicolumn{2}{|c|}{ Chittagong } & \multicolumn{2}{|c|}{$\begin{array}{l}\text { Average of Karachi } \\
\text { and Chittagong } \\
\text { price }\end{array}$} \\
\hline & $\begin{array}{c}\text { Unweight- } \\
\text { ed }\end{array}$ & Weighted & $\begin{array}{c}\text { Unweight- } \\
\text { ed }\end{array}$ & Weighted & $\begin{array}{c}\text { Unweight- } \\
\text { ed }\end{array}$ & Weighted \\
\hline Consumption goods & 2.85 & 2.22 & 2.78 & 2.21 & 2.82 & 2.21 \\
\hline Intermediate goods & 1.97 & 1.93 & 1.94 & 1.86 & 1.95 & 1.89 \\
\hline Capital goods & 2.42 & 2.73 & 2.36 & 2.05 & 2.40 & 2.39 \\
\hline
\end{tabular}

A comparison made between the cost ratios derived from the present study and those derived from the study of domestic prices of imports is given below. The import study relates to the year 1964/65 and hence its findings should appropriately be compared with the cost ratios of the period 1951-66; the cost ratios for the whole period 1951-66 are also given below: 
TABLE A-2

COST RATIOS

\begin{tabular}{|c|c|c|c|c|c|}
\hline \multirow{3}{*}{ 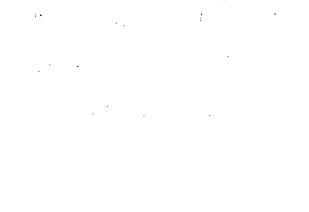 } & \multicolumn{3}{|c|}{ Present study } & \multicolumn{2}{|c|}{ Import study } \\
\hline & $\begin{array}{c}\text { With indirect } \\
\text { tax } \\
\text { unweighted }\end{array}$ & $\begin{array}{c}\text { With indirect } \\
\operatorname{tax} \\
\text { unweighted }\end{array}$ & $\begin{array}{c}\text { With indirect } \\
\text { tax } \\
\text { weighted }\end{array}$ & Unweighted & Weighted \\
\hline & $1951-66$ & $1961-66$ & $1961-66$ & \multicolumn{2}{|c|}{$1964 / 65$} \\
\hline Consumer goods & 1.79 & 2.06 & 1.87 & 2.82 & 2.21 \\
\hline Intermediate goods & 2.03 & 2.08 & 2.10 & 1.95 & 1.89 \\
\hline Capital goods & 1.89 & 2.10 & 2.05 & 2.40 & 2.39 \\
\hline Total: & & 2.09 & 2.02 & 2.38 & 2.21 \\
\hline
\end{tabular}

The average cost ratios (weighted and unweighted) for all commodities as obtained from the import study are generally higher than the cost ratios derived from the direct comparison of ex-factory prices (including taxes) and cif prices. However, when the commodities are grouped into three categories the ratios for consumer and capital goods appear to be distinctly higher in the case of import study than in the present study, whereas the ratios for intermediate ratios are lower in the import study than in the present study. The critical assumption for the use of the domestic prices of imported products to represent comparative cost ratios for the domestic industries is that the ex-factory price is equal to the domestic price of their competitive imports. This assumption may not hold for a number of reasons. In the first place an industry may no longer be an "infant industry" and may have developed competitive efficiency, in which case the domestic price, therefore, falls below the import price plus tariffs and scarcity margins. Tariffs, therefore, become redundant. Secondly, the domestic prices of imports may be higher than the ex-factory prices of domestic competing goods because of consumers' preferences for the imported products. In the extreme case one can conceive of a highly differentiated market for import goods catering to a special clientele. This is specially true for commodities which are the products of international firms and are noticeable in the field of luxury items of consumer goods as well as in the case of drugs and pharmaceuticals and chemicals, etc. Thirdly, the domestic producers may not charge the maximum scarcity price which the comparable and competing imported products may fetch in the market, even though there are only a few domestic producers. Various considerations which induce monopolistic producers not to maximise short-run profits but to take into account various long-run factors affecting their profits may. induce the domestic producers not to exploit the domestic scarcity to the maximum. 
Moreover, the comparison of the results of the present study with those of import study is also inhibited by the fact that the commodities in the two studies are not all comparable. The earlier study includes a number of imported commodities for which no domestic production exists. Hence their domestic prices can not be said to represent what would have been the prices if the commodity is domestically produced, since tariffs and import controls in these cases bear no relation to the need for protecting an existing domestic industry.

In order to obviate this difficulty an attempt has been made to select a few specific items which are common to both the studies.

TABLE A-3

COST RATIOS OF SELECTED ITEMS

\begin{tabular}{c|c|c|c|c}
\hline import study & $\begin{array}{c}\text { Import study } \\
\text { with mark- } \\
\text { up 1964/65 }\end{array}$ & $\begin{array}{c}1964 / 65 \\
\text { without } \\
\text { markup }\end{array}$ & $\begin{array}{c}\text { Present } \\
\text { study } \\
\text { (with taxes) }\end{array}$ \\
\hline
\end{tabular}

Free List Items

Nylon twine and monofilament

Caustic soda

- Sodium bicarbonate

2.72

1.92

1.72

1.97

1965

2.15

1.73

1.55

2.34

1964

Soda ash ...

2.73

2.17

1.94

1965

Acetic acid ...

2.48

2.19

1.95

1.90

1966

Cement ...

1.73

1.54

2.32

1966

G. I. pipe

2.45

2.19

1.89

1965

2.24

1.53

Brass sheets

\subsection{5}

1.36

1.67

1963

Aluminium sheets

1.62

1.47

2.21

1962

1.44

$1.50 \mathrm{a}$

1965

\section{Licensed Items}

Wheat flour

Safety razor blades

3.27

1.39

1.24

$1.32 \mathrm{~b}$

1962

Electric lamp

2.20

3.20

2.85

1.24

1964

Leather belting

1.98

1.76

1.64

1964

1.98

1.77

1.31

1962

Electric meter

1.96

1.75

2.93

1963

2.66

2.38

1.44

1963

Batteries

2.35

2.09

3.02

1965

\section{Bonus Items}

\begin{tabular}{lllllll} 
Sugar & $\ldots$ & 2.90 & 2.89 & 2.58 & 4.55 & 1966 \\
Bicycle & $\ldots$ & 2.74 & 3.33 & 2.97 & 1.84 & 1963 \\
\cline { 4 - 4 } Average: & & & 2.12 & 1.92 & 2.05 &
\end{tabular}


It appears from the above that the unweighted simple average cost ratios for the selected items, which are comparable as between the two studies, are about the same, i.e., 2.12 and 2.05 respectively. The domestic wholesale prices which constitute the basis of the cost ratios in the import study include the normal profit margin of the wholesaler whereas the ex-factory prices which are the basis of the cost ratios in the present study do not include this element, excepting where the producing firm is itself the wholesaler. The indirect evidence suggests that this normal markup may be about 12 per cent. The unweighted average cost ratio after deducting the 12 per cent markup for all the items listed above comes to about 1.92 , as against 2.05 in the present study.

The average ratios conceal significant differences between the individual cost ratios. If we assume that the cif prices of a commodity are the same in both the studies, the differences in cost ratios indicate the differences between the ex-factory prices of the domestic products and the wholesale prices (with and without markup) of the competing imports. Thus, on this assumption, the ex-factory prices of caustic soda, electric meter, G. I. pipe, batteries, and sugar appear significantly higher than the domestic prices of competing imports. This may imply that the abovementioned industries are underprotected and that the domestic and imported items sell at different prices. In the case of cement, safety razor blade, transformer, and bicycle the relative position is reversed with domestic prices being lower than the prices of competing products. In these cases, it is probable that importers do not charge the maximum price that the market will bear. In the case of the rest of the items, cost ratios are comparable. 


\section{Appendix B}

\section{TABLE B-1}

THE COVERAGE OF THE PRESENT STUDY 1

Industry

No. of establishments 1959/60 Census
No. of establishments covered in this analysis

Food manufacturing

460

4.

Alcoholic beverages

233

Silk and artificial silk

Manufacture of textiles, n.e.c.

57

Footwear

\section{$\cdots$}

101

Paper and paper products

$\begin{array}{lll}\cdots & \cdots & 27 \\ \cdots & \cdots & 36\end{array}$

Rubber and rubber products

Chemicals

Basic industrial chemicals

42

Paints and varnishes

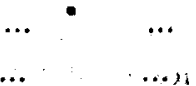

.... is

36

29

Number not known but very large including both smal] and large scale industry)

112

2

8

\section{1}$$
\text { industry) }
$$

27

6.

$$
6
$$

42

(including small scale)

$\begin{array}{lllll}\text { Medicines \& pharmaceuticals } & \ldots & \ldots & 63\end{array}$

$\begin{array}{llll}\text { Perfumes, cosmetics and soaps } & \ldots & \ldots & 80\end{array}$

Matches

$\ldots$
$\ldots$
$\ldots$
$\ldots$

20

19

184 -do-

(includes only soap and number is large including small scale)

$\begin{array}{lllll}\text { Non-metallic minerals } & \ldots & \ldots & \ldots & 83\end{array}$

$\begin{array}{llll}\text { Glass and glass products } & \ldots & \ldots & 29\end{array}$

$\begin{array}{ccccc}\text { Concrete products and non-metallic mineral } & & \\ \text { products, } \text { n.e.c. } & \ldots & \ldots & \ldots & 39\end{array}$

39100

(including small scale)

Manufacture of basic metal

$\begin{array}{lll}\cdots & \quad \cdots \quad 96\end{array}$

31

Metallic products

$\begin{array}{lll}\cdots & \quad \ldots & 467\end{array}$ 
Islam: Comparative Costs. Factor Proportions, and Industrial Efficiency

\section{TABLE B-1 (contd.)}

\begin{tabular}{|c|c|c|c|c|}
\hline Industry & & $\begin{array}{l}\text { No. of estab } \\
1959 / 60 \mathrm{ce}\end{array}$ & $\begin{array}{l}\text { blishments } \\
\text { eensus }\end{array}$ & $\begin{array}{l}\text { No. of establishments } \\
\text { covered in this } \\
\text { analysis }\end{array}$ \\
\hline \multicolumn{2}{|c|}{ Heating, cooking, lighting apparatus } & $\cdots$ & 27 & 5 \\
\hline Cutlery $\quad \ldots$ & $\ldots$ & $\cdots$ & 8 & 4 \\
\hline Utensils $\quad \ldots$ & $\ldots$ & $\cdots$ & 132 & 57 \\
\hline Safes, vaults and trunks $\ldots$ & $\cdots$ & $\cdots$ & 13 & 37 \\
\hline Metal products, n.e.c. $\quad \ldots$ & $\cdots$ & $\therefore$ & 99 & 7 \\
\hline Machinery, non-electrical ... & $\cdots$ & $\cdots$ & 277 & $\because$ \\
\hline Engines and turbines & $\ldots$ & $\ldots$ & 39 & $\stackrel{103}{\text { (including small scale) }}$ \\
\hline Textile machinery and accessories & $\ldots$ & $\cdots$ & $\because$ & 27 \\
\hline Pumps and compressors & $\ldots$ & $\cdots$ & 11 & 2 \\
\hline Electrical machinery & $\cdots$ & $\cdots$ & 104. & 38 \\
\hline Manufacture of transport equipment & $\cdots$ & $\cdots$ & 118 & 6 \\
\hline Manufacture of plastic products & $\ldots$ & $\cdots$ & 56 & $\begin{array}{c}218 \\
\text { (including small scale) }\end{array}$ \\
\hline \multirow{2}{*}{$\begin{array}{c}\text { Manufacture of pens and pencil } \\
\text { products } \ldots \\
\text { Miscellaneous manufacturing industr }\end{array}$} & and & $\begin{array}{r}\text { related } \\
\quad \cdots\end{array}$ & 23 & 3 \\
\hline & Miscellaneous manufacturing industries & $\cdots$ & 57 & 60 \\
\hline
\end{tabular}




\section{REFERENCES :}

1. Soligo, Ronald and J.J. Stern, "Tariff Protection, Import Substitution and Investment Efficiency", Pakistan Development Review, Vol. V, No. 2, Summer 1965, pp. 249-270.

2. Soligo, Ronald and J.J. Stern, "Some Comments on the Export Bonus, Export Promotion and Investment Criteria", Pakistan Development Review, .Vol. VI, No. 1, Spring 1966, pp. 38-56.

3. I.B.R.D., The Industrial Development of Pakistan, 1966. (Washington IBRD).

4. Islam, Nurul, Tariff Protection, Comparative Costs and Industrialization in Pakistan. Mimeographed Research Report No. 57. (Karachi: Pakistan Institute of Development Economics, January 1967).

5. Stern, Joseph J. and Wouter Tims, Inter-Industry Input-Output Tábles for Pakistan, 1962-63. Unpublished Mimeographed Report. (Karachi: Pakistan Institute of Development Economics).

6. Pal, M. L., "Domestic Prices of Imports in Pakistan: Extension of Empirical Findings", Pakistan Development Review, Vol. V, No. 4, Winter 1965.

7. Baqai, Dr. M. and K. Haq, "A Study of Savings in the Corporate Savings in Pakistan, 1959-63". Paper read at the Pakistan Institute of Development Economics Seminar on "Current Economic Problems of Pakistan" held Karachi, January 28-30, 1967.

8. Lary, H. B., Exports of Manufactures by the Less Developed Countries. (New York: National Bureau of Economic Research, Inc., June 1966).

9. Pakistan, Central Statistical Office, Census of Manufacturing Industries, 1955 and 1959-60. (Karachi: Central Statistical Office).

9a. Pakistan, Tariff Commission, Reports, various years. (Karachi: Manager of Publicatians).

10. Basevi, G., "The U.S. Tariff Structure: Estimates of Effective Rates of the U.S. Industries and Industrial Labour", Review of Economics and Statistics, May 1966.

11. Krueger, Anne O., "Some Economic Costs of Exchange Control : The Turkish Case”, Journal of Political Economy, October 1966, pp. 466-480. 